\title{
Perencanaan Masterplan Pasar Niten di Kabupaten Bantul
}

\author{
Rony Gunawan Sunaryo ${ }^{1 *}$, Nicolaus Nino Ardiansyah ${ }^{2}$, Adinda Estiana Saraswati ${ }^{3}$, Adrian Prasetyo Murti ${ }^{4}$ \\ ${ }_{1,2}$ Departemen Arsitektur, Universitas Atma Jaya Yogyakarta, Indonesia \\ 3,4 Alumni Program Studi Arsitektur, Departemen Arsitektur, Universitas Atma Jaya Yogyakarta, Indonesia \\ Email: ronygunawan@uajy.ac.id
}

\section{Received: December 10, 2021 ; Revised: February 14, 2022; Accepted for Publication: March 1, 2022; Published: March 1, 2022}

\begin{abstract}
After the relocation of the old Niten Market to a new location on Jalan Bantul km 5 in 2009, new problems gradually arose which caused the current Niten Market to be deserted. Then came the idea from BAPPEDA (Badan Perencana Pembangunan Daerah) Bantul to revitalize Pasar Niten with a new concept that is more representative, in this case referring to Bantul's strategic value as Daerah Istimewa Yogyakarta sub-urban area. Therefore, we created a new strategy to accommodate trade and economic activity, this typology also becomes the place that can gather various people with different backgrounds in social and ecological aspects. To achieve this strategy, the concept adding the function of agriculture and creative hub through a sustainable food system and placemaking approach to increase the existence of Pasar Niten.
\end{abstract}

Keywords - Masterplan, Pasar Niten, Revitalization, Sustainable Food Systems, Placemaking

Abstrak - Setelah relokasi Pasar Niten lama ke lokasi baru di Jalan Bantul km 5 pada tahun 2009, timbul masalah-masalah baru secara bertahap menyebabkan sepinya pengunjung Pasar Niten di masa kini. Kemudian muncul gagasan BAPPEDA (Badan Perencana Pembangunan Daerah) Bantul untuk merevitalisasi Pasar Niten dengan konsep baru yang lebih representatif, dalam hal ini mengacu pada nilai strategis Bantul sebagai kawasan sub-urban Daerah Istimewa Yogyakarta. Dari permasalahan ini, dibuatlah sebuah strategi yaitu selain sebagai wadah perdagangan dan ekonomi, tipologi turut menjadi wadah yang dapat mengumpulkan berbagai orang dengan latar yang berbeda untuk berdinamika dalam aspek sosial dan ekologi. Dalam mencapai strategi tersebut, diinjeksikan fungsi agriculture dan creative hub melalui pendekatan sustainable food systems dan placemaking sehingga dapat meningkatkan kembali eksistensi Pasar Niten.

Kata Kunci-Masterplan, Pasar Niten, Revitalisasi, Sustainable Food Systems, Placemaking

\section{PENDAhULUAN}

Kabupaten Bantul merupakan kabupaten yang memiliki potensi ekonomi yang cukup besar di bidang pariwisata dan perdagangan. Pasar tradisional di Bantul termasuk dalam salah satu penggerak roda perekonomian dibuktikan dengan sekitar $14 \%$ warga masyarakat Bantul menggantungkan hidupnya di pasar tradisional (Sigid, 2010). Tercatat dalam Dinas Pengendalian Penduduk, Keluarga Berencana, Pemberdayaan Masyarakat Desa (DPPKBPMD) Kabupaten Bantul bahwa pasar rakyat di Bantul hingga saat ini berjumlah 32 pasar yang tersebar di 17 kecamatan.
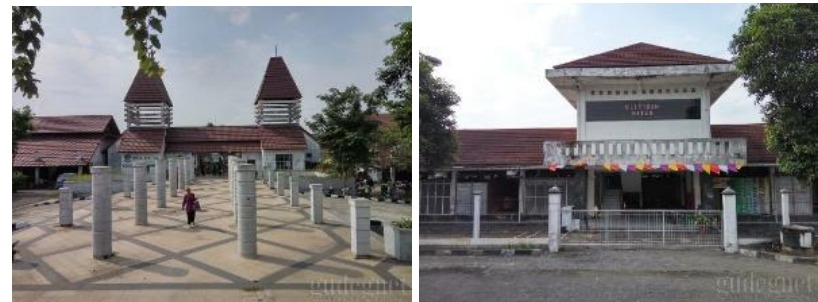

\section{Gambar 1.1 Pasar Niten}

Sumber: Google, 2021

Namun, revitalisasi pada tahun 2009 tidak serta merta menyelesaikan persoalan akan pasar tradisional di Kabupaten Bantul. Dari beberapa pengamatan dan tinjauan ke lapangan, serta wawancara dengan para pedagang setempat, didapatkan beberapa keluhan dan permasalahan baru. Semenjak relokasi ke bangunan baru, justru Pasar Niten Baru (Gambar 1.1) dinilai lebih sepi dari pada sebelumnya. Permasalahan baru yang muncul adalah identitas bangunan pasar yang kurang terlihat, zonasi dan alur sirkulasi yang kurang baik, hingga isu non-fisik seperti trauma masyarakat akan pintu utama pasar (pintu barat) sering terjadi kecelakaan.

Saat ini Pemerintah Daerah Bantul merencanakan untuk merevitalisasi kembali Pasar Niten agar lebih representatif sehingga dapat menghidupkan kembali aktivitas di daerah tersebut dengan mengacu pada SNI 8152:2015 Tentang Pasar Rakyat. Program Badan Perencanaan Pembangunan Daerah (BAPPEDA) Bantul untuk merevitalisasi 32 pasar menjadi latar belakang proyek ini. Gagasan Bappeda Bantul untuk merevitalisasi pasar rakyat menjadi pasar yang dapat menyesuaikan perkembangan di dua puluh tahun ke depan, dengan mengoptimalkan potensi yang ada di Bantul. Pasar tradisional di tahun 2040 direncanakan dengan prinsip sustainable, multi activity, serta menguatkan jatidiri pasar tersebut secara global.

Kabupaten Bantul memiliki keuntungan strategis dalam hal geografis. Letaknya yang berada di sebelah selatan dan tengah Provinsi DIY, dan diapit oleh sungai-sungai besar, menjadikan Kabupaten Bantul memiliki tanah yang subur, sehingga menjadi salah satu wilayah agraris di Provinsi DIY. Ide dan kreativitas masyarakat dalam memanfaatkan alam sebagai sumber penghasil pangan melalui agriculture. Hasil dari agriculture ini menjadi lini sektor utama bagi perekonomian Bantul, mulai dari bahan pangan mentah, hingga hasil olahan yang didukung oleh sentra-sentra industri olahan hasil pangan yang tersebar di seluruh wilayah Bantul. Fungsi Agriculture Park berbasis komunitas dapat menjadi jawaban atas potensi ekonomi, pemanfaatan kekayaan alam, serta edukasi bagi masyarakat maupun wisatawan. 
Salah satu isu utama yang sedang dihadapi Kawasan Perkotaan Kabupaten Bantul adalah alih fungsi lahan pertanian yang mulai marak terjadi di area perkotaan dan sekitarnya. Dikategorikan dalam permasalahan dengan level darurat tinggi, isu ini secara tidak langsung akan berdampak pada sektor ketahanan pangan (food security) di kawasan perkotaan Kabupaten Bantul. Angka kebutuhan (demand) meningkat seiring bertambahnya jumlah penduduk, namun tidak diimbangi dengan persediaan (supply).

Selain ketahanan pangan, rantai pasok pangan (food supply chain) (Gambar 1.2) juga menjadi permasalahan yang terjadi pada sektor pangan. Resiko dan ketidakpastian menjadi isu penting dalam pengelolaan rantai pasok pangan. Kompleksitas dalam sistem ini dinilai tidak efektif dan mengakibatkan banyak permasalahan. Petani sering dirugikan, karena menjual produk hasil tani ke tangan tengkulak/pengepul dengan harga murah, bahkan terkadang hanya menutupi biaya produksi produk. Dikarenakan proses yang panjang tersebut, produk hasil tani memiliki resiko sudah tidak segar lagi, pedagang pasar (retail) kerap membuang bahan-bahan makanan berkondisi buruk karena dianggap tidak layak jual (food loss) yang tentu menambahkan fakta bahwa sistem rantai pasok pangan sangatlah tidak sustainable terhadap lingkungan.

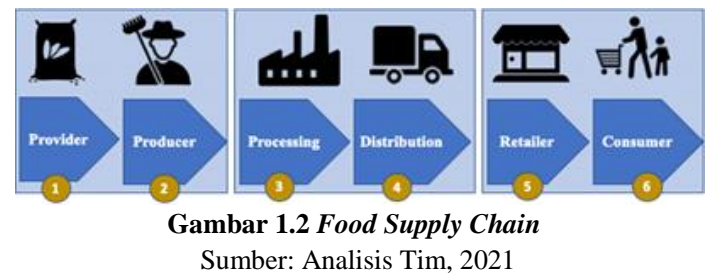

Selain wisata alam, wisata budaya di Bantul terdiri dari bermacam jenis budaya. Terdapat event-event budaya yang diadakan secara rutin setiap tahunnya seperti Bantul Art Festival. Kesenian tradisional jathilan dan kethoprak juga masih sering diadakan di desa-desa tertentu. Setiap desa memiliki produk unggulannya masing-masing khususnya di bidang kerajinan kriya (Gambar 1.3). Berdasarkan data dari Dinas Kebudayaan \& Pariwisata Bantul, terdapat lebih dari 30 desa wisata yang ada di seluruh wilayah Kabupaten Bantul yang berbasis potensi budaya, kerajinan, atau pertanian yang telah dilengkapi dengan fasilitas wisata. Budaya Bantul yang berkaitan dengan sektor industri kreatif menjadi salah satu sumber perekonomian di Kabupaten Bantul karena ekosistem dan modal keahlian yang mendukung.

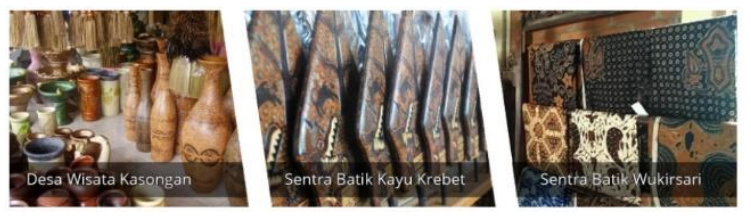

Gambar 1.3 Sentra Kesenian Kabupaten Bantul Sumber: Google, 2021

Seiring perkembangan zaman, seni budaya lokal perlahan mulai ditinggalkan karena masyarakat mulai beralih kepada produk-produk impor. Hal ini disebabkan oleh rasa gengsi yang tidak mau tertinggal oleh tren global. Pengrajin yang tidak melakukan inovasi dan tidak menyesuaikan perkembangan juga semakin tertinggal, diakibatkan oleh ratarata umur pengrajin yang sudah tua (keterbatasan fisik dan biaya), serta penghasilan yang tidak sebanding dengan biaya produksi. Hal ini menyebabkan potensi seni budaya di Bantul mengalami sepi peminat sehingga membutuhkan pengembangan dan pengelolaan hingga dapat bersaing secara global. Selain itu, setelah melakukan beberapa kajian ditemukan beberapa permasalahan pada art space di Bantul yaitu belum terjadi kolaborasi yang signifikan antara pelaku seni dan pengrajin karena masih bergerak sendiri-sendiri, sehingga belum ada satu 'magnet' seni utama di Bantul.

Dari semua isu di atas, maka diperlukan sebuah pemecahan berupa sebuah konsep tipologi yang dapat menjawab berbagai isu mulai dari Pasar Niten Baru yang mengalami penurunan pengunjung, potensi agriculture di kawasan perkotaan, penyelesaian isu food systems yang lebih ramah lingkungan dan berkelanjutan, hingga isu kesenian budaya dan ekonomi kreatif di Kabupaten Bantul. Tipologi ini diharapkan dapat menjadi jawaban dalam meningkatkan eksistensi Pasar Niten, dan menjadi penggerak dalam menjaga kultur sosial budaya masyarakat Bantul, serta menjaga ekologi alam bantul sendiri (sesuai dengan moto Kabupaten Bantul "Bantul, the harmony of nature \& culture").

Dalam mencapai tujuan dan menyelesaikan tuntutan permasalahan dapat menggunakan pendekatan placemaking yang berupaya menghidupkan ruang menjadi sebuah tempat yang memiliki makna khusus dengan mengutamakan pembaruan fungsi dan aktivitas, kenyamanan dan representasi, akses dan konektivitas, serta aspek sosial. Sedangkan sustainable food systems sebagai pengembangan dari teori sustainable architecture dapat menjadi prinsip yang difokuskan dalam menjawab konsep tipologi yang berkelanjutan dan peka terhadap permasalahan di masa sekarang dan di masa yang akan datang. Pendekatan inilah yang menjadi pertimbangan dalam proses konsep rancangan tata ruang luar dan dalam, pemenuhan kebutuhan dan fungsi ruang, hingga aspek fisik dan non-fisik bangunan.

\section{Metode Pengabdian}

\section{A. Observasi Lapangan}

Observasi langsung di lokasi terpilih yaitu Kawasan Pasar Niten untuk mengumpulan data-data yang ada di lapangan. Pengumpulan data diperoleh dari pengamatan secara langsung serta interview/wawancara dengan Dinas Perdagangan Kabupaten Bantul serta pedagang dan pengunjung di Pasar Niten.

\section{B. Studi Literatur}

Pengumpulan data sekunder diperoleh dari studi literatur jurnal, buku dan teori terkait perencanaan masterplan tipologi pasar, serta data-data terkait Pasar Niten yang diperoleh dari Dinas Perdagangan Kabupaten Bantul.

\section{Pengolahan Data}

Data primer dan sekunder yang telah dikumpulkan, diolah untuk memperoleh rumusan permasalahan. Kemudian melakukan analisis mengenai sistem lingkungan, sistem manusia, programatik, perancangan, struktur, serta utilitas dan kelengkapan bangunan. 


\section{Perencanaan Gambar Masterplan}

Penyusunan konsep perencanaan dan perancangan yang dapat menjawab rumusan permasalahan kemudian diterapkan ke dalam desain perancangan.

\section{E. Pentahapan}

Perencanaan tahapan pembangunan sebanyak tiga tahap, yaitu:

1. Pembangunan Pasar Utama (Gambar 2.1) yaitu area basah (pasar daging), area kering (pasar sayur, buah, bumbu, dan kebutuhan rumah tangga) serta Pasar Klithikan.

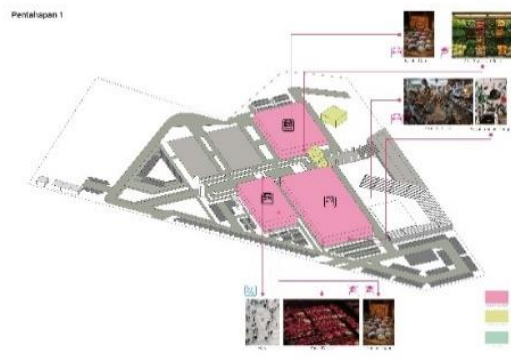

Gambar 2.1 Area Pasar Utama Sumber: Analisis Tim, 2021

2. Penambahan bangunan untuk fungsi baru (Gambar 2.2), seperti area Agriculture dan Pasar Ikan, area Makanan Tradisional dan Creative Hub serta Resto dan area staff.

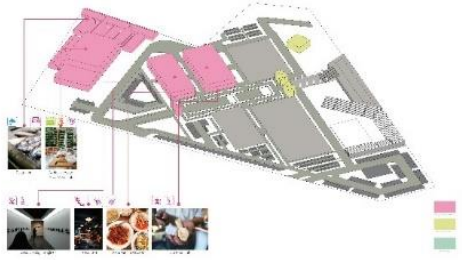

Gambar 2.2 Area Fungsi Baru

Sumber: Analisis Tim, 2021

3. Pembangunan Landscape, Plaza, dan Amphitheatre seperti pada Gambar 2.3.

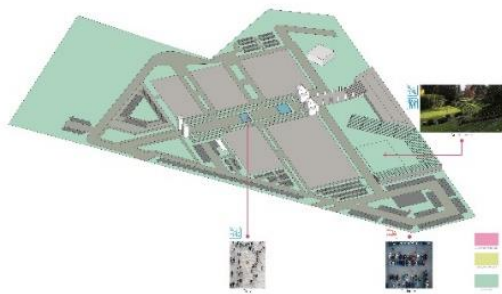

Gambar 2.3 Pengolahan Landscape Sumber: Analisis Tim, 2021

\section{HASIL DAN PEMBAHASAN}

Hasil dan pembahasan perencanaan masterplan Pasar Niten meliputi:

\section{Analisis Sistem Lingkungan}

Analisis konteks kultural mengacu pada perencanaan tipologi yang sebelumnya merupakan pasar tradisional namun diinjeksikan dengan elemen sosial dan budaya yang bertujuan untuk meningkatkan identitas kawasan. Sedangkan konteks fisikal terkait dengan kondisi fisik eksisting seperti kontur dan sungai yang dapat dimanfaatkan untuk desain lanskap, serta struktur eksisting yang dipertahankan dengan metode adaptive reuse ditambahkan suntikan baja WF untuk menopang lantai 2.

2. Analisis Sistem Manusia (Gambar 3.1)

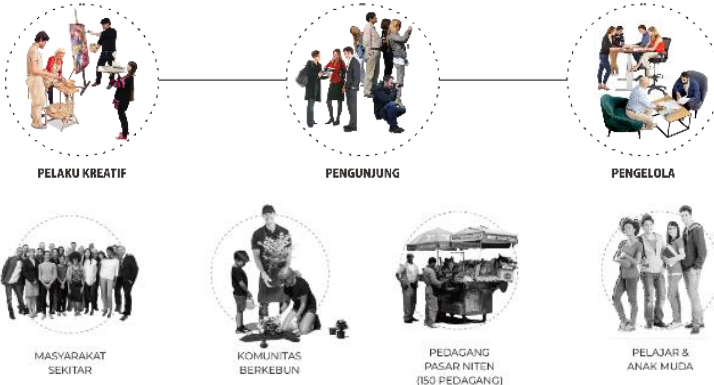

Gambar 3.1 Target Pelaku

Sumber: Analisis Tim, 2021

Target pelaku dikelompokkan menjadi 2 jenis yaitu pelaku yang bergerak di sektor perdagangan, agriculture, dan creative hub (pelaku dalam sektor) serta kalangan masyarakat umum (pelaku di luar sektor).

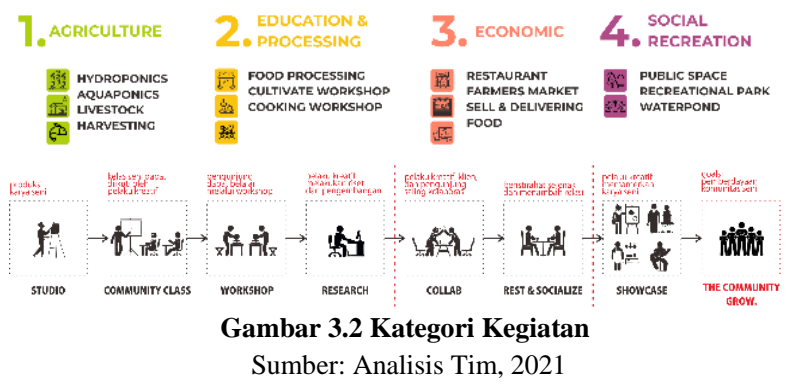

Kegiatan dikategorikan menjadi 2 jenis, yaitu kegiatan yang berhubungan dengan agriculture, serta kegiatan yang berhubungan dengan creative hub. 
3. Analisis Programatik Ruang

Analisis ini mencakup kebutuhan ruang pembagian zonasi dan hubungan antar ruang yang dikelompokkan sebagai pada Tabel 3.1 dan Gambar 3.3 berikut:

\begin{tabular}{|c|c|c|c|c|c|}
\hline 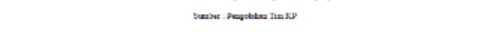 & \multicolumn{5}{|c|}{ A. Ruang untruk Kegiatan Perdagangan } \\
\hline Nama Ruazag & $\underset{\substack{\text { Luas } \\
\text { Ruangan }}}{\text { nat }}$ & Kapusits & $\begin{array}{c}\text { funalat } \\
\text { Rusaug }\end{array}$ & $\begin{array}{l}\text { Lusus Total } \\
\text { Rusangara }\end{array}$ & Zoaing \\
\hline $\begin{array}{c}\text { Asea Keruag } \\
\text { (peralatan } \\
\text { numalit) }\end{array}$ & $9 \mathrm{~m}^{3}$ & 6 Oamg & $96 \mathrm{Kios}$ & $908 \mathrm{~m}^{3}$ & Publik \\
\hline $\begin{array}{c}\text { Ares } \\
\text { Khituliks }\end{array}$ & $9 \mathrm{~m}^{2}$ & 6 Orans & 96 Kios & $867 \mathrm{~m}^{4}$ & Publik \\
\hline $\begin{array}{c}\text { Astea } \\
\text { Thassan }\end{array}$ & $120 \mathrm{ur}^{2}$ & $\begin{array}{l}=15.20 \\
\text { pedazgang }\end{array}$ & 1 Asea & $120 \mathrm{~m}^{2}$ & Publik \\
\hline 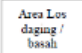 & $6.2 \mathrm{~m}^{3}$ & 40 amg & $58 \mathrm{los}$ & $365.08 \mathrm{~m}^{2}$ & Publis \\
\hline $\begin{array}{c}\text { Ares sayur } \\
\text { \& bualt }\end{array}$ & $6,2 \mathrm{~m}^{2}$ & 4 Orass & 189 los & $1.173,6 \mathrm{~m}^{2}$ & Publik \\
\hline 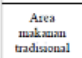 & $9 \mathrm{~m}^{2}$ & 6 Orang & 64 los & $802,5 \mathrm{mi}^{5}$ & Publik \\
\hline 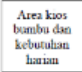 & $9 \mathrm{~m}^{2}$ & 6 Otang & $82 \operatorname{los}$ & $584.56 \mathrm{~m}^{2}$ & Publis \\
\hline Placa Pass & $1341,81 \mathrm{~m}^{2}$ & - & 1 Asea & $1341.81 \mathrm{~m}^{2}$ & Publik \\
\hline $\begin{array}{l}\text { Infuruation } \\
\text { Ceater }\end{array}$ & $15 \mathrm{~m}^{2}$ & 2 Orang & 3 Tempat & $44,8 \mathrm{~m}^{2}$ & Publik \\
\hline $\begin{array}{l}\text { Area Gudang } \\
\text { Pasar }\end{array}$ & $14,5 \mathrm{~m}^{2}$ & Barang & 12 gudang & $189,1 \mathrm{mi}^{2}$ & Semu Private \\
\hline $\begin{array}{l}\text { Area Gudang } \\
\text { Restausasot }\end{array}$ & $19,5 \mathrm{~m}^{3}$ & Barang & 1 Gudang & $19,5 \mathrm{~m}^{\prime}$ & Semi Private \\
\hline
\end{tabular}

$$
\text { B. Ruang ustuk Keziatan Pendukumz }
$$

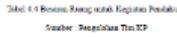

\begin{tabular}{|c|c|c|c|c|c|}
\hline $\begin{array}{c}\text { Arex } \\
\text { Pertanian }\end{array}$ & $1.114 \Psi^{2}$ & 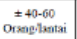 & 2 & $2.228 .5 \mathrm{~m}^{2}$ & Publiz \\
\hline Area Ilan & $144 \mathrm{~m}^{t}$ & Iran & 9 & $1.295 \mathrm{~m}^{\prime}$ & Publiz \\
\hline 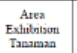 & $442,8 \mathrm{~m}^{2}$ & $\begin{array}{l} \pm+0 .-60 \\
\text { Oasang }\end{array}$ & 1 & $442,8 \mathrm{~m}^{2}$ & Publik \\
\hline $\begin{array}{l}\text { Area } \\
\text { Restantat }\end{array}$ & $320,30 \mathrm{~m}^{2}$ & 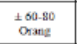 & 1 & $320.36 \mathrm{~m}^{\prime}$ & Pablik \\
\hline $\begin{array}{c}\text { Areas Displuy } \\
\text { Kerajunan }\end{array}$ & $431.14 \mathrm{~m}^{2}$ & 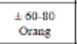 & 1 & $431.14 \mathrm{~m}^{\prime}$ & Pablitir \\
\hline $\begin{array}{c}\text { Astea } \\
\text { Pectubustan } \\
\text { Kerajinan }\end{array}$ & $5,5 \mathrm{~m}^{2}$ & 2 Orass & 32 & $176 \mathrm{~m}^{3}$ & Puthik \\
\hline ATM Center & $15 \mathrm{~m}^{\prime}$ & 60rang & 2 & $30 \mathrm{~m}^{2}$ & Pablik \\
\hline
\end{tabular}

C. Raang utruk Peageloth

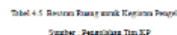

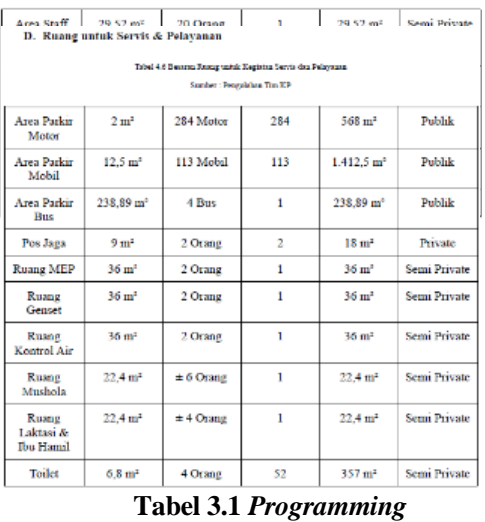

Sumber: Analisis Tim, 2021

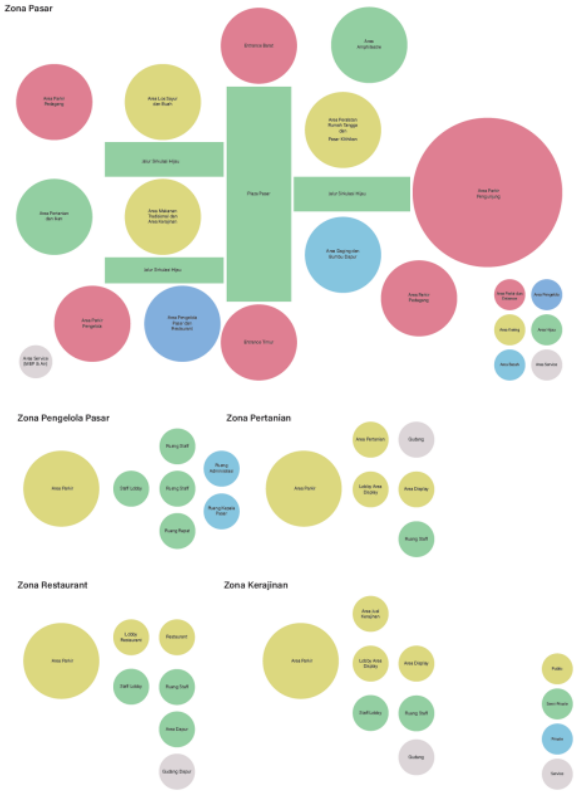

Gambar 3.3 Hubungan Antar Ruang Sumber: Analisis Tim, 2021

4. Analisis Perancangan Arsitektur, Struktur, dan Utilitas

Dari hasil analisis tapak (Gambar 3.4) terpilih skala mikro, didapatkan beberapa kesimpulan peletakan zoning yang merespon kondisi tapak sebagai berikut:

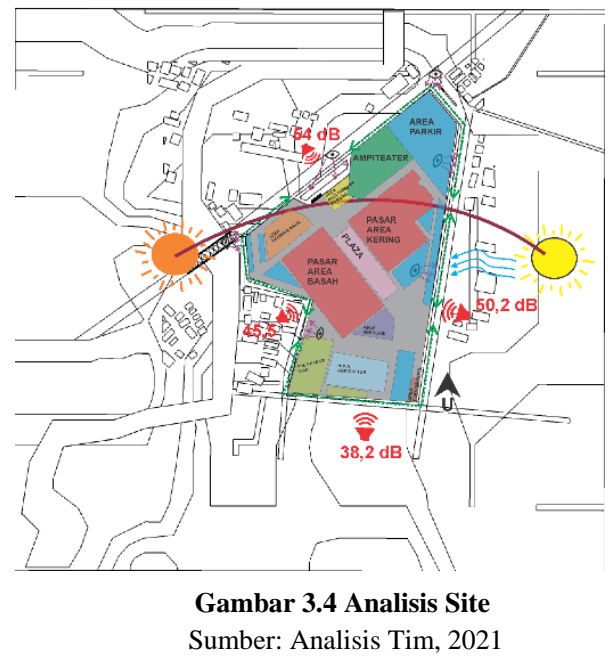

- Memisahkan entrance menyesuaikan SNI Pasar Rakyat Tipe A dengan jumlah 1 pintu masuk dan 2 pintu keluar

- Menambahkan island sebagai divider jalan pada pertigaan jalan sisi timur (J1. Ps. Niten) untuk memperlebar jalan.

- Menambahkan jalur pedestrian mengelilingi site untuk sirkulasi pejalan kaki.

- Meletakkan bangunan utama di tengah site dengan vegetasi di sekeliling site sebagai sound barrier dan memecah cahaya matahari yang masuk ke site. 
- Pengaturan zoning menggunakan strategi Pocket Attraction guna meratakan pergerakan pengunjung mengitari sekeliling pasar. Pocket Attraction terdiri atas amphitheatre, area agriculture, plaza, taman, dan area perikanan,

- Menempatkan area perikanan di sisi Barat dekat dengan Sungai Winongo sekaligus sebagai salah satu daya tarik Pasar Niten.

Analisis struktur pada bangunan dibedakan menjadi tiga. Sub structure menggunakan pondasi footplat, super structure menggunakan sistem rangka kaku dengan penambahan baja WF yang digabungkan dengan kolom eksisting untuk menyangga beban lantai 2, sedangkan upper structure menggunakan sistem atap pelana dari baja ringan serta atap joglo dari struktur kayu.

Analisis utilitas pada perancangan masterplan mencakup jaringan air bersih, jaringan air kotor, sisem ME bangunan, sistem proteksi kebakaran, sistem penanggulangan petir, serta sistem transportasi vertikal.

5. Konsep Perencanaan dan Perancangan (Gambar 3.5)

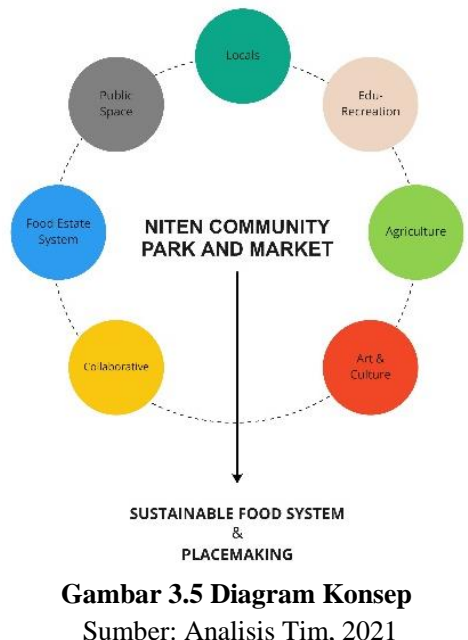

Konsep perencanaan tipologi yang diinjeksikan ke dalam Pasar Niten, diperuntukan bagi semua golongan masyarakat (public space) sehingga dapat memberdayakan pedagang dan komunitas. Konsep (Gambar 3.6 dan Gambar 3.7) diimplementasikan ke dalam beberapa pilihan kegiatan tour, workshop, shopping, dan ruang terbuka publik.

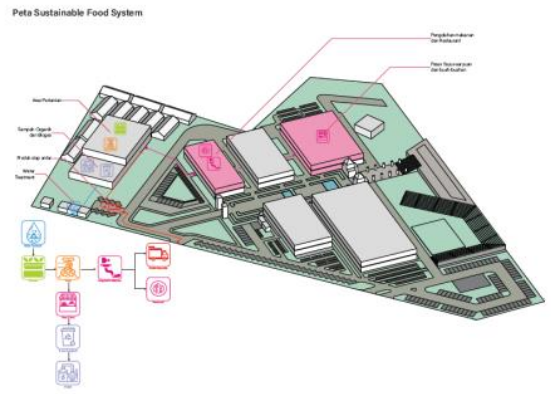

Gambar 3.6 Konsep Sustainable Food Systems Sumber: Analisis Tim, 2021
Sustainable Food Systems adalah sistem pangan yang memberikan ketahanan pangan dan nutrisi bagi semua sedemikian rupa dengan berbasis ekonomi, sosial dan lingkungan, untuk menghasilkan ketahanan pangan dan nutrisi untuk generasi mendatang. (FAO, 2014). Konsep Sustainable Food Systems terdiri dari 9 tahapan yang saling berhubungan, dengan urutan yaitu sumber air yang di olah oleh water treatment plants lalu dialiri sebagai pengairan pada tanaman, untuk selanjutnya dipanen dan di distribusikan pada 3 pilihan, Distribusi pertama menuju Pasar Tani, dimana Pasar Tani menghasilkan sampah organik dari sisa-sisa komoditas perdagangan yang tidak laku, dapat diolah pada fasilitaas biogas. Sedangkan distribusi selanjutnya dapat dijual ke luar maupun menjadi bahan baku bagi restaurant.

Pendekatan placemaking memiliki makna proses dalam mentransformasukan sebuah tempat dengan maksud menemukan kembali nilai sebuah ruang (Project for Public Spaces, 1990). Penerapannya diimplementasikan ke dalam desain dengan cara menempatkan ruang-ruang kreatif seperti studio sebagai wadah karya para seniman serta area workshop yang dapat diikuti juga oleh pengunjung. Adanya ruang-ruang kreatif (Creative $\mathrm{Hub}$ ) ini akan meramaikan aktivitas dan menghidupkan kembali eksistensi Pasar Niten.

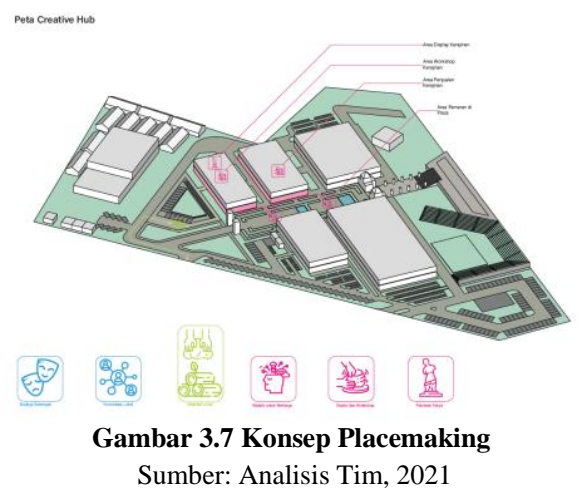

Berikut merupakan implementasi desain dalam wujud tata ruang dan bangunan:

1. Zoning (Gambar 3.8), terbagi menjadi 6 zona yaitu zona display tanaman, zona area los sayur, zona area los daging, zona area makanan, zona area tlasaran, dan zona area peralatan dan klithikan.

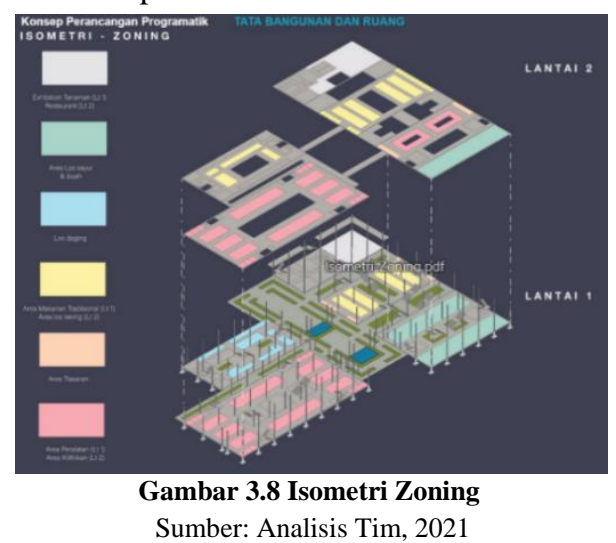


2. Struktur (Gambar 3.9), pada bagian atap menggunakan struktur atap pelana, bagian struktur bangunan menggunakan struktur baja wf, dan pada bagian pondasi menggunakan pondasi footplate.

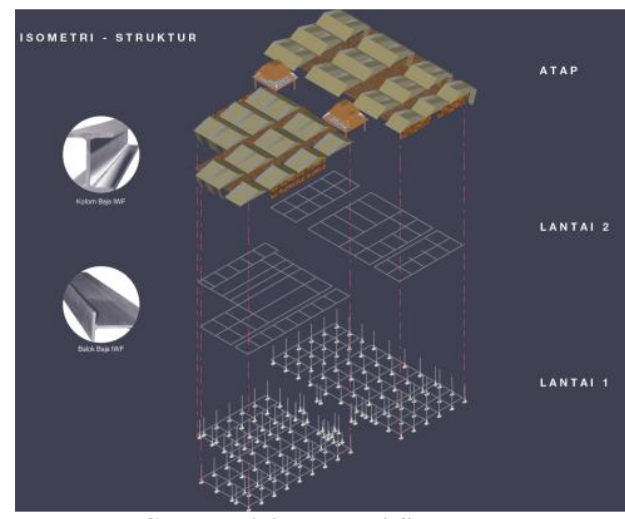

Gambar 3.9 Isometri Struktur

Sumber: Analisis Tim, 2021

3. Sirkulasi (Gambar 3.10), terbagi menjadi 3 kategori yaitu sirkulasi menuju pasar, sirkulasi penghubung massa, dan sirkulasi dalam pasar.

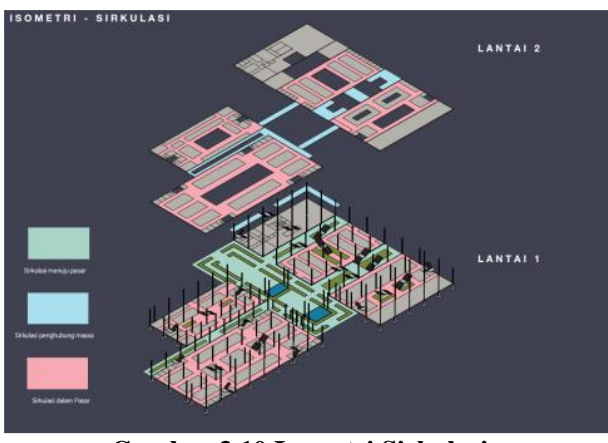

Gambar 3.10 Isometri Sirkulas

Sumber: Analisis Tim, 2021

4. Utilitas (Gambar 3.11), terdiri dari sistem pengairan air bersih, sistem pengairan air kotor, kelistrikan, serta tanggap kebakaran.

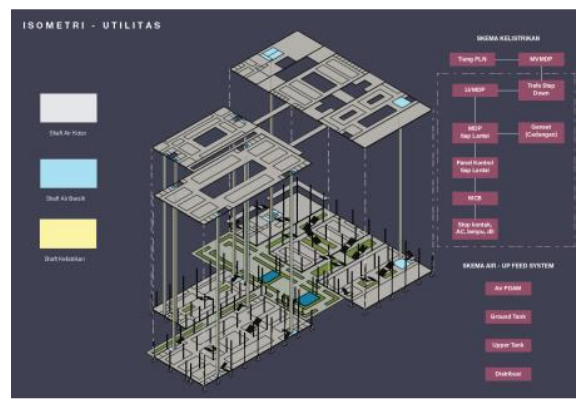

Gambar 3.11 Isometri Utilitas

Sumber: Analisis Tim, 2021
Terdapat juga implementasi konsep desain yang di tunjukan dengan gambar perspektif yaitu sebagai berikut:
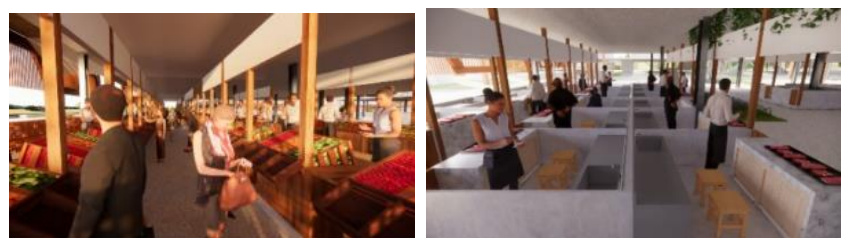

Gambar 3.12 Perspektif Area Pasar Basah Sumber: Analisis Tim, 2021

Area basah (Gambar 3.12) terletak di sisi barat pada lantai satu dan lantai dua. Pada los daging menggunakan modul meja lapak dan keran air sehingga mengatasi kumuh pada los daging.
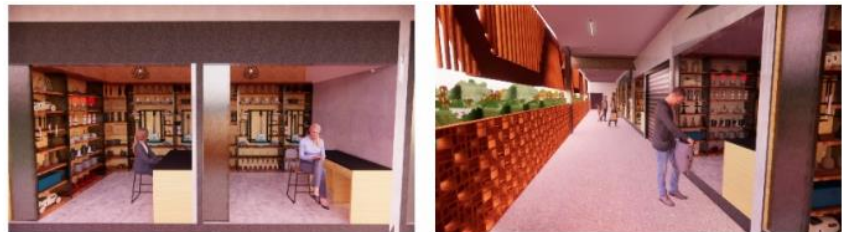

Gambar 3.13 Perspektif Area Kios Pasar Klithikan Sumber: Analisis Tim, 2021

Area Pasar Klithikan (Gambar 3.13) barangbarang bekas ditata dengan menarik pada los dan kios yang dirancang menggunakan rak display. Selain itu tidak ada barang yang berserakan seperti permasalahan pada pasar klithikan yang lama yang mengganggu visual pengunjung.
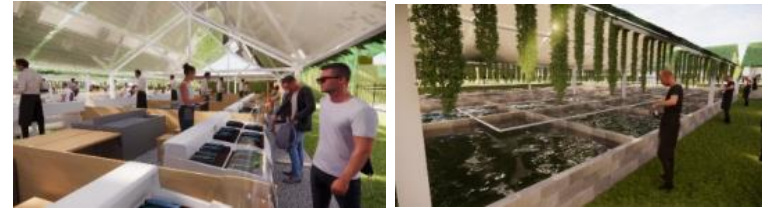

Gambar 3.14 Perspektif Pasar Ikan Sumber: Analisis Tim, 2021

Site yang dekat dengan Sungai Winongo memiliki potensi untuk memanfaatkan sungai sebagai pengairan area penangkaran ikan menggunakan Teknik water wheel pump untuk menghemat energi. Setelah ikan dipanen langsung disuplai menuju restoran dan diperjualbelikan di area los pasar ikan (Gambar 3.14). Jenis ikan konsumsi yang akan ditangkarkan adalah ikan lele, nila, mas, gurameh, dan bawal.

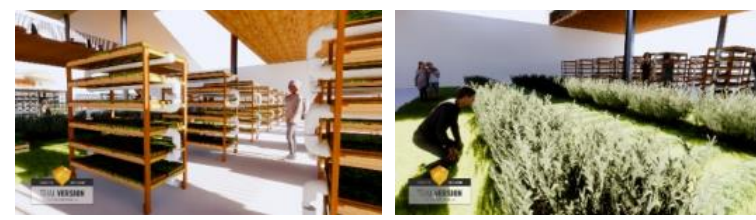

Gambar 3.15 Perspektif Area Agriculture Sumber: Analisis Tim, 2021 
Pada area agrikultur (Gambar 3.15) pengunjung dapat melihat penanaman tanaman secara langsung dengan Teknik hidroponik. Pengunjung juga dapat mengikuti workshop menanam. Hasil panen tanaman yang segar maupun hasil olahan dapat dibeli oleh pengunjung di area display lantai 2.
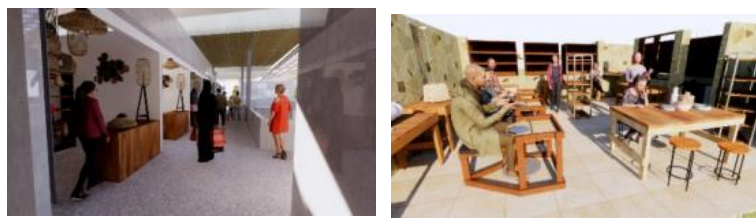

Gambar 3.16 Perspektif Area Workshop dan Display Kerajinan

Sumber: Analisis Tim, 2021

Pedagang kerajinan dapat menata barang dagangan pada los yang sudah disediakan. Dengan penataan yang atraktif dapat mengundang pengunjung. Bagi pengunjung yang tertarik untuk belajar membuat kerajinan kriya disediakan ruang workshop (Gambar 3.16). Terdapat juga gallery display barang kerajinan untuk display pameran.
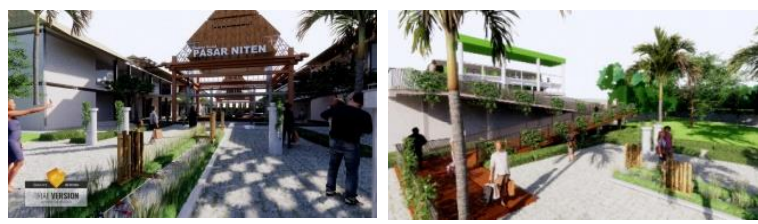

Gambar 3.17 Perspektif Area Entrance Sumber: Analisis Tim, 2021

Area entrance (Gambar 3.17) yang ikonik terlihat pada pion-pion khas Pasar Niten dan atap joglo pada sisi Barat. Disediakan ramp dari jalan raya menuju area pasar karena kontur yang menurun dan untuk memfasilitasi penyandang disabilitas. Penambahan kolam dan vegetasi untuk menurunkan suhu lingkungan dan sebagai daya tarik baru.

\section{KESIMPULAN}

Pengabdian masyarakat untuk Masterplan Pasar Niten merupakan bentuk kerjasama dari Institusi Fakultas Teknik Universitas Atma Jaya Yogyakarta dengan Pemerintah Daerah Kabupaten Bantul. Melalui penyusunan kegiatan yang meliputi proses panjang dari observasi, sampai dengan desain, didapatkan hasil berupa produk masterplan yang optimal untuk mendukung pelestarian pasar tradisional dan mendorong pengembangan potensi baru yang diinjeksikan ke dalam desain pasar.

Kendala yang dialami pada penyusunan masterplan adalah keadaan pandemi, yang menyebabkan proses observasi tidak menggambarkan saat kondisi normal sehingga perlu kajian lebih lanjut ketika pandemi sudah berlalu. Selain itu diperlukan evaluasi terkait akomodasi kapasitas, komoditas, serta jumlah pedagang pasca pandemi. Kajian masterplan ini juga terbatas pada kajian-kajian arsitektural sehingga perlu pengembangan kajian yang lebih luas serta multi-disiplin pada bidang ekonomi, sosial, hingga teknologi.industri
Harapan dari kegiatan ini ialah Masterplan Pasar ini dapat dijadikan role model dalam revitalisasi pasar tradisional. Tidak saja bagi Pemerintah Daerah Kabupaten Bantul, namun juga di wilayah lain yang memiliki pasar tradisional yang mengangkat potensi lokal, tidak hanya dari aspek ekonomi, namun juga sosial dan ekologi.

\section{UCAPAN TERIMAKASIH}

Kegiatan pengabdian masyarakat Masterplan Pasar Niten merupakan kerjasama antara Fakultas Teknik Universitas Atma Jaya Yogyakarta dengan BAPPEDA Kabupaten Bantul dengan sponsor kegiatan oleh Lembaga Penelitian dan Pengabdian Masyarakat UAJY. Pelaksanaan pekerjaan Masterplan melibatkan kontribusi tim mahasiswa Kerja Praktek Prodi Arsitektur Semester Gasal 2020-2021 yaitu: Amelinda Agnes Monica, Anastasia Lavenzky, Jonathan Timotius.

\section{DAFTAR PUSTAKA}

[1] Food and Agriculture Organization of the United Nations, "Sustainable Food Systems, Concept and Framework", 2014.

[2] Project for Public Spaces, "What If We Built Our Cities Around Places?", 2004.

[3] Sigid, Prof. Dr. R. Rijanta, "Peranserta Stakeholder Dalam Pengelolaan Pasar Tradisional di Kabupaten Bantul, Magister Perencanaan Kota dan Daerah", 2010.

[4] Badan Standardisasi Nasional, SNI 8152:2015 Tentang Pasar Rakyat, 2015.

\section{TIM (HEADING 5)}

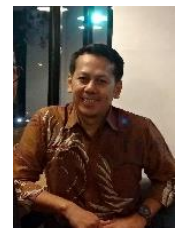

Dr. Rony Gunawan Sunaryo, S.T., M.T., prodi Arsitektur, Fakultas Teknik, Universitas Atma Jaya Yogyakarta.

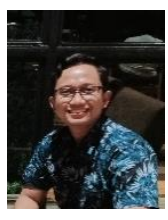

Nicolaus Nino Ardiansyah, S.T., M.Sc., prodi Arsitektur, Fakultas Teknik, Universitas Atma Jaya Yogyakarta.

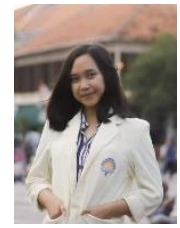

Adinda Estiana Saraswati, prodi Arsitektur, Fakultas Teknik, Universitas Atma Jaya Yogyakarta.

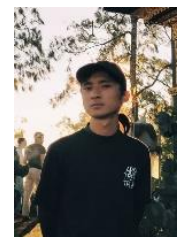

Adrian Prasetyo Murti, prodi Arsitektur, Fakultas Teknik, Universitas Atma Jaya Yogyakarta. 